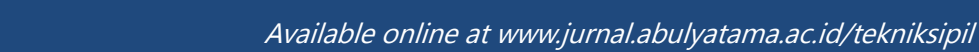 ISSN 2407-9200 (Online) \\ Universitas Abulyatama Jurnal Teknik Sipil Unaya
}

\section{Desain Ulang Balok dan Kolom Komposit}

\author{
Syafridal Is ${ }^{1}$, Muhammad Zardi ${ }^{1^{*}}$, Nanda Mahathir ${ }^{1}$ \\ ${ }^{1}$ Program Studi Teknik Sipil, Fakultas Teknik, Universitas Abulyatama, Jl. Blang Bintang \\ Lama Km 8,5 Lampoh Keude Aceh Besar, 23372, Aceh, Indonesia \\ *Email korespondensi: muhammadzardi_sipil@abulyatama.ac.id
}

Diterima 19 Mei 2019; Disetujui 26 Juli 2019; Dipublikasi 31 Juli 2019

\begin{abstract}
The aim of this study is to redesign the beams and columns of reinforced concrete into a composite structure of Women's Empowerment and Child Protection Agency to derive a comparison of strength and efficiency between concrete-steel composite structures and reinforced concrete structures without changing the layout of columns and beams in the initial planning. LRFD (Load Resistance Factor Design) method and SAP2000 ver.14 as a tool were used in this study. The design was based on Indonesian Standard Regulation. The concrete strength $\left(f^{\prime}\right.$ 'c) and steel strength $\left(f_{y}\right)$ were $25 \mathrm{MPa}$ and $250 \mathrm{MPa}$, respectively. In this study, steel profile BJ 37of WF (400x $400 \times 21 \times 21)$ $\mathrm{mm}$ was used for beam and WF (400x 400x $30 \times 50) \mathrm{mm}$ with concrete cross section (500 $\times 500) \mathrm{mm}$ for column. The results of redesign composite structure for three-story building with the designed steel profile is fulfilled the strength requirements. The obtained maximum moment of beam and column are $36789,36 \mathrm{~kg} . \mathrm{cm}$ and $43942,2 \mathrm{~kg} . \mathrm{cm}$, respectively. The used of composite material is $76,925 \%$ more expensive than reinforced concrete material.
\end{abstract}

Keywords : LRFD, SAP2000, steel composite, load, beam, and column

\begin{abstract}
Abstrak: Penulisan jurnal ini bertujuan untuk mendesain ulang balok dan kolom dari beton bertulang ke komposit pada Pembangunan Gedung Badan Pemberdayaan Perempuan dan Perlindungan Anak Banda Aceh, untuk memperoleh perbandingan kekuatan dan efesiensi antara struktur komposit bajabeton dan struktur beton bertulang tanpa mengubah tata letak kolom dan balok pada perencanaan awal. Perencanaan menggunakan metode LRFD (Load Resistance Factor Design), dan untuk perhitungan menggunakan SAP2000 versi 14. Perencanaan mengacu pada SNI (Standar Nasional Indonesia). Mutu beton $\left(f^{\prime} c\right)$ yang digunakan adalah $25 \mathrm{MPa}$ dan mutu baja $\left(f_{y}\right)$ adalah $250 \mathrm{MPa}$. Pada jurnal ini direncanakan profil penampang balok baja komposit adalah WF (400 x 400 x 21 x 21) $\mathrm{mm}$ dan profil penampang kolom baja komposit WF (400 x 400x 30 x 50) mm, dengan penampang beton $(500 \times 500) \mathrm{mm}$, dan menggunakan BJ 37 . Hasil dari desain ulang balok dan kolom komposit untuk bangunan gedung 3 lantai dengan profil yang direncakan memenuhi persyaratan kekuatan dengan momen maksimum yang dihasilkan pada balok dan kolom adalah $36.789,36 \mathrm{~kg}$.cm dan 43.942,2 kg.cm, berturut-turut. Pemakaian material baja komposit biayanya lebih mahal dari pada menggunakan material beton bertulang. Perbandingan biaya antara material beton bertulang dengan material komposit adalah 76,925\%.
\end{abstract}

Kata kunci : LRFD, SAP2000, baja komposit, beban, balok, dan kolom

Perkembangan ilmu pengetahuan dan teknologi

di berbagai bidang saat ini mengalami kemajuan yang sangat pesat. Pemenuhan kebutuhan akan tempat tinggal dan aktivitasnya mengakibatkan 
semakin besarnya permintaan akan ruang, sementara lahan yang tersedia terbatas. Bangunan bertingkat tinggi merupakan alternatif terbaik untuk memenuhi kebutuhan akan ruang yang terus meningkat. Bangunan bertingkat tinggi harus memperhatikan faktor alam, faktor struktur, keamanan dan kenyamanan penghuninya.

Baja merupakan salah satu material paling umum ditemui di lapangan. Baja mempunyai kekuatan yang besar dalam memikul gaya tarik dan tekanan, tanpa membutuhkan volume yang besar. Seiring berjalannya waktu ditemukan inovasi- novasi baru yang mendudukung terciptanya satu konstruksi yang kokoh, dengan gabungan baja dan beton atau lebih dikenal struktur baja komposit.

Penggunaan metode komposit pada struktur gedung akan meningkatkan kekakuan dan mengurangi waktu getar alami. Dengan catatan dari semua aspek perhitungan maupun kontrol yang kiranya mendukung suatu struktur tersebut tercapai situasi dan kondisi yang aman.

Selain pemilihan material yang tepat, hal yang terpenting dalam perencanaan struktur adalah memastikan kekakuan bangunan tersebut dari resiko kegagagalan struktur akibat beban gempa.

Sehubungan dengan konstruksi komposit yang saat ini telah berkembang, ada beberapa hal yang perlu diperhatikan dari segi kekuatan dan efisiensi. Oleh karena itu, tujuan penulisan jurnal ini adalah mendesain ulang balok dan kolom dari beton bertulang ke komposit, untuk memperoleh perbandingan kekuatan dan efesiensi antara struktur komposit baja-beton dan struktur beton bertulang tanpa mengubah tata letak kolom dan balok pada perencanaan awal. Pada jurnal ini mengambil objek desain ulang balok dan kolom komposit pada Pembangunan Gedung Badan Pemberdayaan Perempuan dan Perlindungan Anak. yang terletak di Gampong Jeulingke, kecamatan Syiah Kuala, kabupaten Banda Aceh, provinsi Aceh dengan luas bangunan \pm 574.50 $m^{2}$.

\section{KAJIAN PUSTAKA}

\section{Pembebanan}

Menurut (SNI 1729-2013), struktur gedung harus direncanakan kekuatan terhadap pembebanan tetap dan pembebanan sementara. Pembebanan tetap adalah kombinasi antara beban mati dan beban hidup, sedangkan pembebanan sementara adalah kombinasi antara beban tetap dan beban angin atau beban gempa.

\section{Beban Mati}

Menurut (SNI 1729-2013), berat semua bagian dari suatu gedung yang bersifat tetap, yang termasuk dalam elemen konstruksi gedung seperti : dinding, lantai, atap, plafon, tangga, finishing, dan termasuk segala beban tambahan, serta peralatan tetap yang merupakan bagian yang tak terpisahkan dari gedung tersebut.

\section{Beban Hidup}

Menurut (SNI 1729-2013), Beban hidup adalah beban yang dapat berpindah-pindah, seperti : penghuni, perabot, mesin-mesin, peralatan, dan timbunan-timbunan barang. Meskipun dapat berpindah-pindah, beban 
hidup masih dapat dikatakan bekerja secara perlahan-lahan pada struktur.

\section{Beban Angin}

Beban angin adalah semua beban yang bekerja pada gedung atau bagian gedung yang disebabkan oleh terjadinya selisih tekanan udara. Daniel L. Schodek (1999) menjelaskan, struktur yang berada pada lintasan angin akan menyebabkan angin berbelok atau dapat berhenti. Hal ini mengakibatkan energi kinetik angin berubah bentuk menjadi energi potensial berupa tekanan atau hisapan pada struktur. Besar tekan atau hisap yang diakibatkan oleh angin bergantung pada banyak faktor. Salah satu faktor yang mempengaruhi adalah kecepatan angin.

Tekanan tiup harus diambil minimum 25 $\mathrm{kg} / \mathrm{m}^{2}$ untuk kondisi umum. Sedangkan untuk daerah tepi laut sampai sejauh $5 \mathrm{~km}$ dari pantai harus diambil sebesar $40 \mathrm{~kg} / \mathrm{m}^{2}$, kecuali untuk daerah pantai atau daerah lain yang mungkin dapat menimbulkan tekan yang lebih besar lagi, maka tekanan tiup $(p)$ harus di hitung dengan rumus:

$$
p=\frac{V^{2}}{16}
$$

atau

$$
W=w \cdot p \cdot A
$$

\section{Beban Gempa}

Efek gempa berasal dari inersia internal yang arahnya horizontal yang disebabkan oleh adanya percepatan tanah (ground acceleration).

Dalam penentuan gempa suatu bangunan dipermukaan tanah atau penentuan amplifikasi besaran percepatan beban gempa puncak dari batuan dasar pada suatu situs atau lokasi, diperlukan suatu tinjauan guna klasifikasi jenis tanah dari batuan dasar pada lokasi situs tersebut. Hal tersebut dapat ditinjau melalui lokasi situs pada peta persebaran gempa.

Akumulasi gempa di Indonesia telah diatur dalam SNI 1726-2012. Menurut peraturan yang berlaku terdapat sejumlah peta wilayah gempa yang dibagi menurut percepatan respon gempa pada batuan dasar.

Untuk mendapatkan gaya geser yang ditimbulkan oleh gaya gempa maka diperlukan sejumlah parameter yang dapat dihitung secara matermatis. Parameter yang digunakan dalam perencanaan pembebanan gempa pada struktur gedung menurut SNI 1726-2012 adalah:

a. Kelas lokasi tanah

Dalam perumusan suatu bangunan dipermukaan tanah atau penentuan amplifikasi besaran percepatan beban gempa puncak dari batuan dasar kepermukaan tanah untuk suatu situs diperlukan klasifikasi kelas situs.

b. Koefisien amplifikasi getaran

Faktor amplifikasi getaran meliputi percepatan getaran periode pendek $\left(F_{a}\right)$ yang dapat diakumulasi dari Tabel 1 dan percepatan periode 1 detik $\left(F_{v}\right)$ yang dapat diakumulasi dari Tabel 2:

c. Parameter respon spectra 
Menurut SNI 1726-2012 (6.2) nilai parameter percepatan respon spectra dapat dikalukulasi dengan persamaan berikut:

$$
\begin{aligned}
& S_{M S}=F_{a} S_{S} \\
& S_{M 1}=F_{v} S_{l}
\end{aligned}
$$

Tabel 1 Koefisien Periode Pendek, $F_{a}$

\begin{tabular}{|c|c|c|c|c|c|}
\hline $\begin{array}{c}\text { Kelas } \\
\text { situs }\end{array}$ & \multicolumn{5}{|c|}{$\begin{array}{c}\text { Parameter respons spektral percepatan gempa } \\
\text { perioda pendek, } \mathrm{T}=0,2 \text { detik, } S_{\boldsymbol{R}} \text { ) terpetakan pada }\end{array}$} \\
\hline & $S_{s} \leq 0,25$ & $S_{s}=0,5$ & $S_{s}=0,75$ & $S_{s}=1,0$ & $S_{s} \geq 1,25$ \\
\hline$S A$ & 0,8 & 0,8 & 0,8 & 0,8 & 0,8 \\
\hline$S B$ & 1,0 & 1,0 & 1,0 & 1,0 & 1,0 \\
\hline$S C$ & 1,2 & 1,2 & 1,1 & 1,0 & 1,0 \\
\hline$S D$ & 1,6 & 1,4 & 1,2 & 1,1 & 1,0 \\
\hline$S E$ & 2,5 & 1,7 & 1,2 & 0,9 & 0,9 \\
\hline$S F$ & \multicolumn{5}{|c|}{$S^{b}$} \\
\hline
\end{tabular}

Tabel 2 Koefisien Periode 1 Detik, $F_{v}$

\begin{tabular}{|c|c|c|c|c|c|}
\hline $\begin{array}{c}\text { Kelas } \\
\text { situs }\end{array}$ & \multicolumn{5}{|c|}{ Parameter respons spektral percepatan gempa MCE } \\
perioda 1 derpetikikan pada
\end{tabular}

d. Gaya geser dasar $(V)$

Nilai gaya geser dasar yang bekerja pada gedung dapat dikalkulasikan dengan persamaan:

$$
V=W_{i} C_{s}
$$

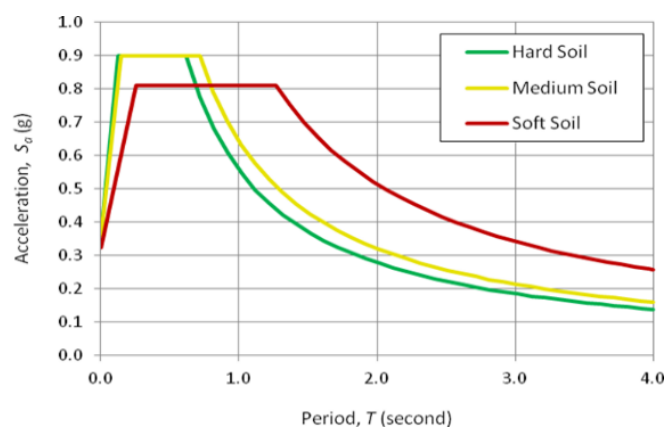

Gambar 1 Respon Spectra Untuk Kota Banda Aceh

Sumber:

https://www.researchgate.net/profile/Reni $\mathrm{Su}$ ryanita/publication

e. Gaya desain $\left(F_{i}\right)$

Nilai geser design $\left(F_{i}\right)$ merupakan nilai gaya geser yang bekerja pada setiap lantai gedung. Gaya design ini bekerja pada titik berat struktur dan diproyeksikan menurut sumber kerja $\mathrm{x}$ dan $\mathrm{y}$. Nilai geser design struktur gedung menurut SNI 1726-2012 pasal (7.10.1.1) adalah:

$$
F_{i}=\frac{W i z i}{\sum_{i=1}^{n} W i z_{i}} V
$$

\section{Kombinasi Pembebanan}

Berdasarkan peraturan yang berlaku pada SNI 1727-2013 tentang beban minimum Perencanaan Bangunan, digunakan kombinasi pembebanan sebagai berikut :

1. $1.4 \mathrm{D}$

2. $1.2 D+1.6 L+0.5 R$

3. $1.2 \mathrm{D}+1.6 \mathrm{R}+0.5 \mathrm{~W}$

4. $1.2 \mathrm{D}+1.0 \mathrm{~W}+L+0.5 R$

5. $1.2 D+1 E+L$

6. $0.9 D+1 W$

7. $0.9 D+1 E$

\section{Program SAP2000}

Program SAP2000 merupakan salah satu software yang telah dikenal luas dalam dunia teknik sipil, terutama dalam bidang analisis struktur dan elemen hingga (finite elemen). Pembuat perangkat lunak SAP yaitu CSi (Computer and Structure, Inc) yang berasal dari Berkeley, California USA, telah mengembangkan program ini sejak tahun 1970-an. Seri program SAP (Structural Analysis Program) untuk komputer PC yang dilahirkan pertama kali adalah SAP80, kemudian disusul dengan SAP90. Namun kedua program tersebut masih menggunakan operasi DOS, dan untuk perancangan elemen strukturnya masih menggunakan program tersendiri, sehingga dirasakan cukup merepotkan pengguna.

Seiring dengan kemajuan teknologi 
komputer yang begitu pesat, pembuat perangkat lunak SAP tersebut mengeluarkan seri program SAP2000 yang merupakan perangkat lunak untuk analisis dan desain struktur yang menggunakan operasi windows. SAP2000 salah satu program analisis struktur yang lengkap, namun mudah untuk dioprasikan.

Prinsip utama penggunaan program ini adalah pemodelan struktur, eksekusi analisis, dan pemeriksaan atau optimsi desain, yang semuanya dapat dilakukan dalam satu lagkah atau satu tampilan. Tampilan berupa model secara real time sehingga memudahkan pengguna untuk melakukan pemodelan secara menyeluruh dalam waktu singkat namun dengan hasil yang cepat.

Output yang dihasilkan juga dapat ditampilkan sesuai dengan kebutuhan baik berupa model struktur, grafik, mapun spreadsheet. Semuanya dapat disesuaikan dengan kebutuhan untuk penyusunan laporan analisis dan desain.

Analisis SAP2000 menggunakan finite element method baik untuk static analysis maupun dynamic analysis (non-linear analysis). Semuanya terintegrasi dalam satu paket yang dilengkapi dengan beberapa data base untuk keperluan analisis dan desain seperti: data base tampang struktur untuk berbagai bentuk, mulai dari yang simetris hingga asimetris. Namun SAP tidak bisa menghitung material komposit.

Beberapa kemampuan yang dimiliki oleh SAP2000 antara lain:

1. Analisis yang cepat dan akurat
2. Model pembebanan yang lebih lengkap baik berupa static loading maupun dynamic loading.

3. Pemodelan elemen shell yang lebih akurat

4. Analisis dinamik dengan Ritz dan Eigenvalue.

5. Sistem koordinat ganda untuk bentuk geometri struktur yang kompleks.

Fasilitas desain yang disediakan program ini hanya untuk struktur beton dan baja dengan menggunakan peraturan perencanaan dari Amerika, Eropa serta negara lainnya. Perencanaan dengan menggunakan peraturan Indonesia dapat dilakukan dengan cara memodifikasi beberapa faktor reduksi kekuatan.

\section{Analisa Struktur}

Portal adalah struktur yang terdiri atas elemen-elemen linear, umumnya balok dan kolom, pada perencanaannya menahan semua beban yang bekerja melalui kolom dan diteruskan ke pondasi. Portal menerima beban vertikal dan beban horizontal. Beban vertikal akibat beban tetap, sedangkan beban horizontal akibat beban gempa atau beban angin. Perhitungan portal menggunakan bantuan SAP2000 versi 14.

\section{Balok Komposit}

Menurut Bowles (1980), balok komposit (composite beam) adalah balok yang kekuatannya bergantung pada interaksi mekanis diantara dua atau lebih bahan. Balok 
salah satu di antara elemen-elemen struktur yang paling banyak dijumpai pada setiap struktur. Balok adalah elemen struktur yang memikul beban yang bekerja tegak lurus dengan sumbu longitudinalnya. Hal ini akan menyebabkan balok melentur. Beberapa jenis balok komposit antara lain:

a. Balok komposit penuh

Untuk balok komposit penuh, penghubung geser harus disediakan dalam jumlah yang memadai sehingga balok mampu mencapai kuat lentur maksimumnya. Pada penentuan distribusi tegangan elastis, slip antara baja dan beton dianggap tidak terjadi (SNI 031729-2002 pasal 12.2.6).

b. Balok komposit parsial

Pada balok komposit parsial, kekuatan balok dalam memikul lentur dibatasi oleh kekuatan penghubung geser, terlihat pada Gambar 2(a). Perhitungan elastis untuk balok seperti ini, seperti pada penentuan defleksi atau tegangan akibat beban layan, harus mempertimbangkan pengaruh adanya slip antara baja dan beton (SNI 03-1729- 2002 pasal 12.2.7).

c. Balok baja yang diberi selubung beton

Walaupun tidak diberi angker, balok baja yang diberi selubung beton di semua permukaannya dianggap bekerja secara komposit dengan beton, terlihat pada Gambar 2(b), selama hal-hal berikut ini dipenuhi:

1. Tebal minimum selubung beton yang menyelimuti baja tidak kurang daripada $50 \mathrm{~mm}$, kecuali yang disebutkan pada Butir 12.2.8(2) di bawah;
2. Posisi tepi atas balok baja tidak boleh kurang daripada $40 \mathrm{~mm}$ di bawah sisi atas pelat beton dan $50 \mathrm{~mm}$ di atas sisi bawah pelat;

3. Selubung beton harus diberi kawat jaring atau baja tulangan dengan jumlah yang memadai untuk menghindari terlepasnya bagian selubung tersebut pada saat balok memikul beban.
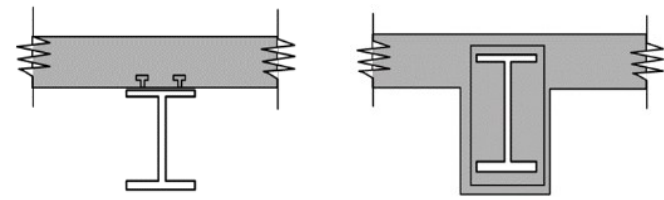

(a) Balok komposit parsial

(b) Balok baja yang diselubungi beton

Gambar 2 Balok Komposit

Sumber: Segui, W (2007)

\section{Kuat Lentur Nominal}

1. Kekuatan Lentur Positif

Kekuatan lentur positif desain $\emptyset_{b} M_{n}$ dan kekuatan lentur positif yang diizinkan $M_{n} /$ $\Omega_{b}$ harus di tentukan untuk keadaan batas leleh $\emptyset_{b}=0,90$ dan $\Omega_{b}=1,67$.

a. Untuk $\frac{h}{t_{w}} \leq 3,75 \sqrt{\frac{E}{f_{y}}}$

$M_{n}$ harus ditentukan dari distribusi tegangan plastis pada penampang komposit untuk keadaan batas leleh (momen plastis).

b. Untuk $\frac{h}{t_{w}} \geq 3,75 \sqrt{\frac{E}{f_{y}}}$

$M_{n}$ harus ditentukan dari superposisi tegangan elastis, dengan memperhitungkan efek penopongan, untuk keadaan batas leleh (momen leleh).

2. Kekuatan Lentur Negatif 
Kekuatan lentur negatif tersedia harus ditentukan untuk penampang baja sendiri. Alternatif kekuatan lentur negatif yang tersedia harus ditentukan dari distribusi tegangan plastis pada penampang komposit untuk keadaan batas leleh (momen plastis), dimana $\emptyset_{b}=0,90$ dan $\Omega_{b}=1,67$.

Kekuatan lentur nominal yang dihitung berdasarkan distribusi tegangan plastis, dapat dikatagorikan menjadi dua kasus sebagai berikut :

1. Sumbu netral plastis jatuh pada pelat beton

Dengan mengaju pada Gambar 3(a),

kuat lentur nominal dapat di hitung dari Gambar 3(b):

$M_{n}=C \cdot d_{1}$

atau

$$
M_{n}=T \cdot d_{1}=A_{s} \cdot f_{y} \cdot\left(\frac{d}{2}+t_{s}-\frac{\alpha}{2}\right)
$$

2. Sumbu netral plastis jatuh pada profil baja Apabila ke dalam blok tegangan beton $\alpha$, ternyata melebihi tebal pelat beton, maka distribusi tegangan dapat ditunjukkan seperti pada Gambar 3(c).

Kuat lentur nominal diperoleh dengan persamaan berikut:

$$
M_{u}=C_{c} \cdot d_{2}^{\prime}+C_{s} \cdot d_{2}^{\prime}
$$

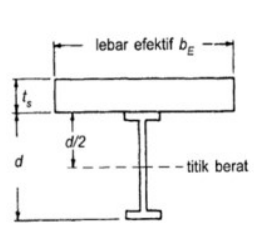

(a)

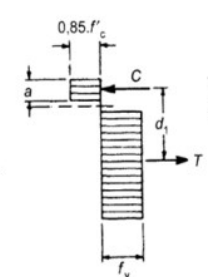

(b)

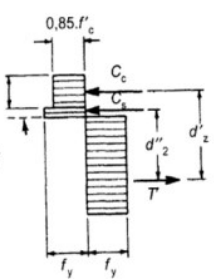

(c)
Gambar 3 Kuat Lentur Nominal Berdasarkan Distribusi Tegangan Leleh Sumber: Segui, W (2007)

\section{Penghubung Geser (Shear Connector)}

Gaya geser yang terjadi antara pelat beton dan profil baja harus dipikul oleh sejumlah penghubung geser, sehingga tidak terjadi slip pada saat masa layan. Besarnya gaya geser horizontal yang harus dipikul oleh penghubung geser diatur dalam SNI 03-1729 -2002 pasal 12.6.2. Pasal ini menyatakan bahwa untuk aksi komposit dimana beton mengalami gaya tekan akibat lentur.

Dalam merencanakan alat sambung geser dapat dilaksanakan berdasarkan kuat desak beton $\left(C_{\max }\right)$ dan kuat tarik baja $\left(T_{\max }\right)$. Dipilih yang terbesar sehingga menghasilkan jumlah alat sambung geser yang lebih banyak. Banyaknya alat sambung geser yang dibutuhkan dapat dihitung dengan rumus:

$$
N=\frac{C_{\max }}{Q_{n}}=\frac{T_{\max }}{Q_{n}}
$$

\section{Kolom Komposit}

Menurut Salmon dan Jonson (1996), kolom komposit didefinisikan sebagai kolom baja yang dibuat dari potongan baja giling (rolled) built-up dan di cor di dalam beton struktural atau terbuat dari tabung atau pipa baja dan diisi dengan beton structural. Menurut SNI 03-1729-2002, ada dua tipe kolom komposit, dapat dilihat pada Gambar 4, yaitu :

1. Kolom komposit yang terbuat dari profil baja yang diberi selubung beton di sekelilingnya (kolom baja berselubung beton).

2. Kolom komposit terbuat dari penampang baja berongga (kolom baja berintikan beton). 
Untuk komponen struktur komposit terbungkus beton, pembatasan berikut harus dipenuhi sesuai SNI 1729-2015 pasal I1.3 dan I2.1.1a :

1. Beton harus memiliki kekuatan tekan $f^{\prime}{ }_{c}$ tidak kurang dari $3 \mathrm{ksi}(21 \mathrm{MPa})$ atau tidak lebih dari $10 \mathrm{ksi}(70 \mathrm{MPa})$ untuk beton normal dan tidak kurang dari 3 ksi (21 MPa) atau tidak lebih dari $6 \mathrm{ksi}$ (42 MPa) untuk beton ringan.

2. Tegangan leleh minimum disyaratkan dari baja struktural dan batang tulangan perkuat digunakan dalam perhitungan kekuatan komponen struktur komposit tidak boleh melebihi $75 \mathrm{ksi}(525 \mathrm{MPa})$.

3. Luas penampang melintang inti baja harus terdiri dari sedikitnya $1 \%$ dari penampang melintang komposit total.

4. Selongsong beton dari inti baja harus ditulangi dengan batang tulangan longitudinal menerus dan sengkang pengikat lateral atau spiral. Bila dingunakan pengikat lateral, batang tulangan No. $3 \quad(10 \mathrm{~mm})$ berspasi maksimum 12 in $(305 \mathrm{~mm})$ pusat ke pusat, atau batang tulangan No. 4 (13 $\mathrm{mm}$ ) atau lebih besar harus digunan spasi minimum 16 in $(406 \mathrm{~mm})$ pusat ke pusat. Boleh digunakan tulangan kawat ulir atau kawat dilas dengan luas ekivalen. Spasi maksimum dari pengikat lateral tidak boleh melebihi 0,5 kali dimensi kolom terkecil.

5. Rasio tulangan minimum $\rho_{s r}$ sebesar 0,004 digunakan untuk penulangan longitudinal menerus, dimana $\rho_{s r}$ adalah:

$$
\rho_{s r}=\frac{A_{s r}}{A_{g}}
$$

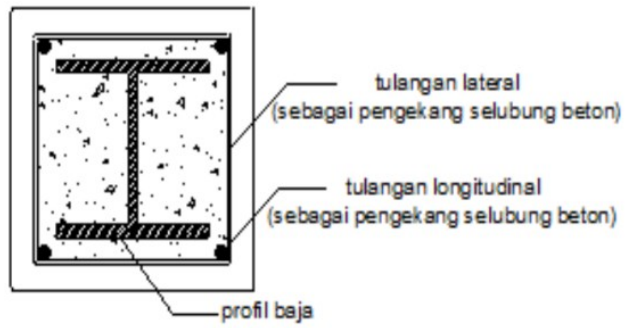

(a) Kolom komposit dari profil baja

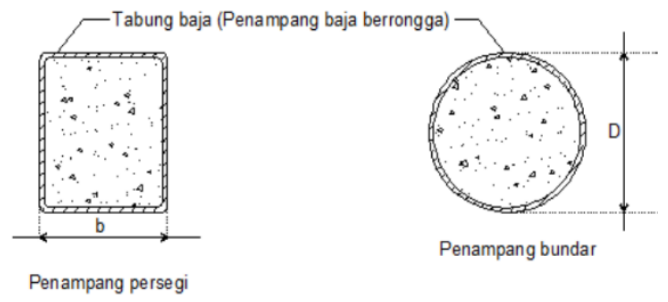

(b) Kolom komposit dari baja berongga

\section{Gambar 4 Kolom Komposit}

Sumber: Segui, W (2007)

Tata cara perhitungan kuat rencana kolom komposit diatur dalam SNI 03-1729002 pasal 12.3.2.

\section{Sambungan}

Perencanaan sistem sambungan balokkolom yang mengacu pada peraturan SNI 03-1729-2015 tentang spesifikasi untuk bangunan gedung baja struktural. Jenis sambungan yang bekerja pada balok- kolom adalah sambungan plat ujung.

\section{METODE PERENCANAAN}

Data yang digunakan pada jurnal ini diperoleh dari kontraktor pelaksana yaitu PT. Tenaga Inti, sedangkan untuk data lain yang diperlukan diambil dari literatur dan SNI. 


\section{Spesifikasi dan Data Struktur}

1. Lantai gedung menggunakan bahan beton bertulang dengan $f_{c}^{\prime}=25 \mathrm{MPa}$ $\operatorname{dan} f_{y}=240 \mathrm{MPa}$.

2. Struktur utama (balok dan kolom) menggunakan bahan baja, mutu baja BJ 37.

3. Gedung terdiri dari 3 (tiga) lantai dan fungsi gedung untuk pemberdayaan perempuan dan perlindungan anak dengan beban hidup $250 \mathrm{~kg} / \mathrm{m}^{2}$ (SNI 1727-2013).

\section{Pembebanan dan Desain Struktur Komposit}

Beban mati yang diperhitungkan dalam struktur gedung ini adalah beban elemen struktur gedung yang memiliki fungsi struktural maupun non struktural. Untuk menghitung besarnya beban mati suatu elemen dilakukan dengan meninjau berat satuan material tersebut berdasarkan volume elemen.

Untuk beban hidup, beban angin dan beban gempa dihitung berdasarkan peraturan SNI seperti yang dijelaskan pada tinjauan kepustakaan.

Struktur komposit yang digunakan pada penulisan jurnal ini adalah balok komposit parsial dan kolom komposit yang terbuat dari profil baja. Perhitungan dilakukan berdasarkan ketentuan SNI.

Diagram alir perencaan ini terlihat pada Gambar 5.

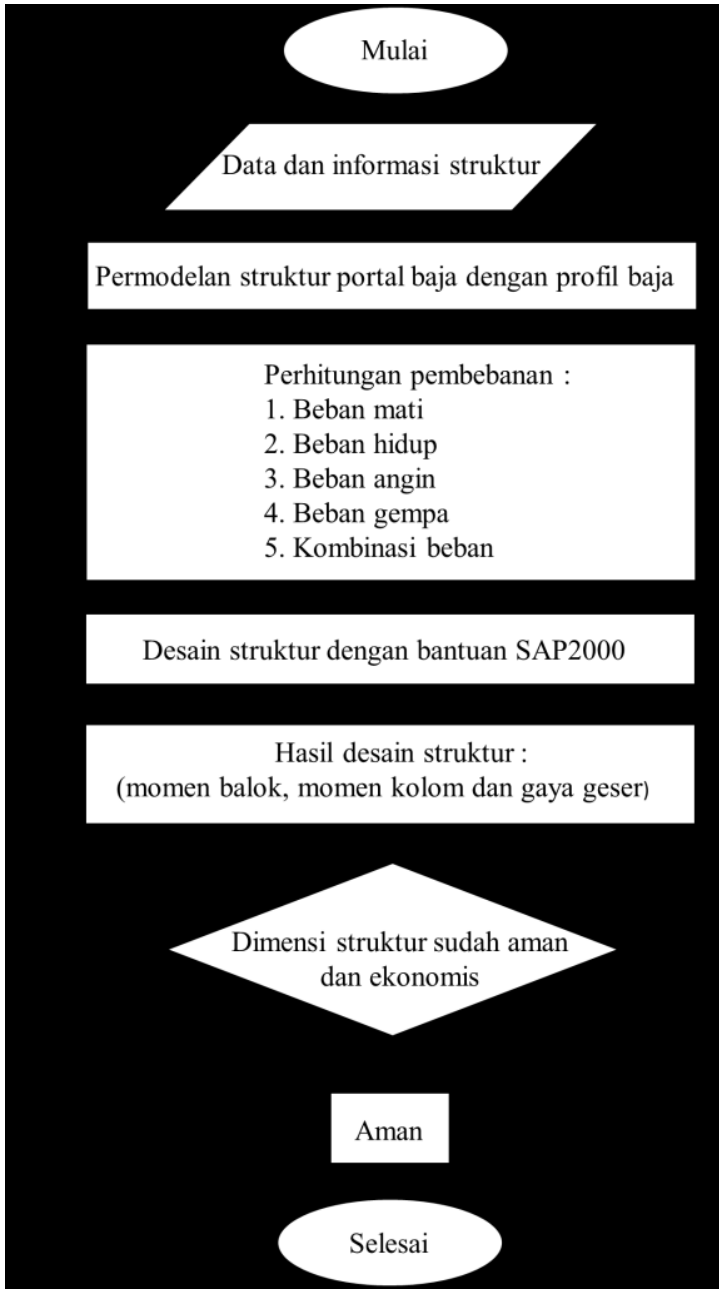

Gambar 5 Bagan Alir Perencanaan

\section{HASIL PEMBAHASAN}

Pada jurnal ini direncanakan struktur portal menggunakan baja komposit, dari struktur portal sebelumnya yang menggunakan beton bertulang. Permodelan 3D dengan menggunakan program SAP2000 dapat dilihat pada Gambar 6 . 


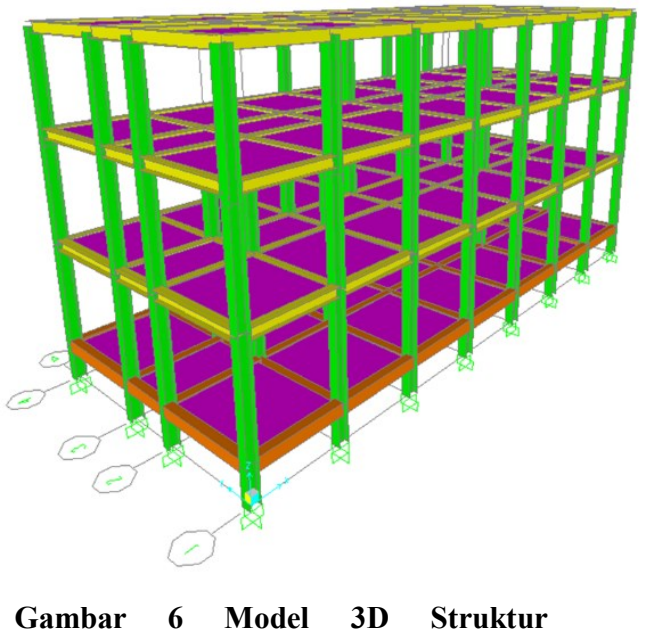

\section{Desain struktur utama}

Perhitungan perencanaan struktur utama diawali dengan penggunaan program analisa struktur dengan mengambil nilai gaya-gaya dalam yang dihasilkan oleh program tersebut. Dalam hal ini struktur utama dimodelkan sebagai rangka terbuka karena dinding bata tidak diasumsikan sebagai pemikul beban. Pemikul diasumsikan terjadi pada balok parsial, kolom komposit, pelat lantai dan pelat atap. Untuk struktur utama, bagian yang direncanakan adalah balok komposit parsial, kolom komposit di selubung beton dan pelat lantai.

Profil baja untuk kolom dan balok yang memenuhi ketentuan kekuatan dan efisien terhadap biaya diperoleh WF (400x400x21x21) mm untuk balok dan WF (400x400x30x50) mm, dengan penampang beton $(500 \times 500)$ untuk kolom. Momen maksimum yang dihasilkan pada balok dan kolom adalah 36789,36 kg.cm dan 43942,2 kg.cm, berturut-turut. Sedangkan untuk gaya geser, diperoleh sebesar 19637,08 kg.cm.

\section{KESIMPULAN DAN SARAN}

\section{Kesimpulan}

Berdasarkan hasil perencanaan ulang menggunakan program SAP2000, diperoleh beberapa kesimpulan sebagai berikut:

1. Profil penampang balok baja komposit yang aman pada desain ini adalah WF (400x400x21x21) $\mathrm{mm}$ dengan memakai penghubung geser tipe stud dan menggunakan BJ 37.

2. Profil penampang kolom baja komposit yang aman pada desain ini adalah WF $(400 \times 400 \times 30 \times 50) \mathrm{mm}$, dengan penampang beton $(500 \times 500)$ mm. dan menggunakan BJ 37.

3. Sambungan yang digunakan adalah rigid connection dan digunakan baut ASTM A325 dengan diameter $30 \mathrm{~mm}$.

4. Momen maksimum pada balok adalah $36789,36 \mathrm{~kg} . \mathrm{cm}$ dan pada kolom sebesar 43942,2 kg.cm. Gaya geser maksimum yang diperoleh adalah sebesar 19637,08 kg.cm.

5. Perbandingan biaya antara material beton bertulang terhadap material komposit untuk bangunan tiga lantai adalah $76,925 \%$.

\section{Saran}

Untuk mendapatkan hasil yang sesuai dengan diharapkan dimana hasilnya mendekati kondisi sesungguhnya di lapangan, maka perlu adanya pendalaman studi yang lebih terhadap ini. Terutama pertimbangan terhadap aspek-aspek lain yang sangat mempengaruhi kondisi sebenarnya yaitu aspek teknis, ekonomi, dan estetika, sehingga 
diharapkan bangunan yang dihasilkan betulbetul seperti sebenarnya yang lebih kuat, ekonomis dan pelaksaannya tepat waktu.

\section{DAFTAR PUSTAKA}

Budi setiawan. (2015). Perencanaan Struktur Baja Komposit Pada Gedung Hotel-Q Denpasar Bali Dengan Sistem Rangka Pemikul Momen : didapat dari : www. Depositoryusu.com

Handi Pramono \& rekan. (2006). 17 Aplikasi rekayasa Konstruksi Menggunakan SAP2000 versi 9. Jakarta: PT. Elex Media Komputindo

Handi Pramono dkk. (2007). 12 Tutorial dan Latihan Desain Konstruksi dengan SAP2000 versi 9. Yogyakarta: CV. Andi Offset.

Setiawan, Agus. (2008). Perencanaan Struktur Baja Dengan Metode LRFD (Load Resistance and Factor Design). Jakarta : Erlangga

SNI - 1726. (2012). Tata Cara Perencanaan Ketahanan Gempa Untuk Struktural Gedung dan Non Gedung. Jakarta:BSN

SNI - 1727. (2013). Beban Minimum Untuk Perancangan Bangunan Gedung Dan Struktur Lain. Jakarta : BSN

SNI - 1729. (2015). Spesifikasi Bangunan Baja Structural. Jakarta : BSN

SNI - 7833. (2012). Tata Cara Perencangan Beton Pracetak Dan Beton Prategang Untuk Bangunan Gedung. Jakarta: BSN
SNI 03 - 1729. (2002). Tata Cara Perecanaan Struktur Baja Untuk Bangunan gedung. Jakarta : BSN

T.Segui, W. (2007). Steel Desain (Fourth Edition). Canada: by Nelson.
- How to cite this paper :

Is, S., Zardi, M., \& Mahathir, N. (2019). Desain Ulang Balok dan Kolom Komposit. Jurnal Teknik Sipil Unaya, 5(2), 76-86. 